\title{
High-quality-draft genome sequence of the heavy metal resistant and exopolysaccharides producing bacterium Mucilaginibacter pedocola TBZ30
}

\author{
Xia Fan, Jingwei Tang, Li Nie, Jing Huang and Gejiao Wang ${ }^{*}$
}

\begin{abstract}
Mucilaginibacter pedocola TBZ30 ${ }^{\top}$ ( CCTCC AB $2015301^{\top}=$ KCTC 42833 ${ }^{\top}$ ) is a Gram- negative, rod-shaped, nonmotile and non-spore-forming bacterium isolated from a heavy metal contaminated paddy field. It shows resistance to multiple heavy metals and can adsorb/remove $\mathrm{Zn}^{2+}$ and $\mathrm{Cd}^{2+}$ during cultivation. In addition, strain $\mathrm{TBZ}^{\top} \mathrm{T}^{\top}$ produces exopolysaccharides (EPS). These features make it a great potential to bioremediate heavy metal contamination and biotechnical application. Here we describe the genome sequence and annotation of strain TBZ30 ${ }^{\top}$. The genome size is 7,035,113 bp, contains 3132 protein-coding genes (2736 with predicted functions), 50 tRNA encoding genes and 14 rRNA encoding genes. Putative heavy metal resistant genes and EPS associated genes are found in the genome.
\end{abstract}

Keywords: Mucilaginibacter pedocola, Genome sequence, Heavy metal resistance, Exopolysaccharides

\section{Introduction}

The genus Mucilaginibacter was first established by Pankratov et al. in 2007 and the type species is Mucilaginibacter paludis [1]. The common characteristics of this genus are Gram-negative, non-spore-forming, nonmotile, rod-shaped and producing exopolysaccharides (EPS) [1, 2]. EPS are long-chain polysaccharides and consist of branched, repeating units of sugars or sugar derivatives [3]. EPS producing bacteria play an important role in environmental bioremediation such as water treatment, sludge dewatering and metal removal [4]. So far, genomic features of Mucilaginibacter strains are less studied.

Mucilaginibacter pedocola $\mathrm{TBZ}^{\mathrm{T}}{ }^{\mathrm{T}}(=\mathrm{CCTCC} \mathrm{AB}$ $2015301^{\mathrm{T}}=$ KCTC $42833^{\mathrm{T}}$ ) was isolated from a heavy metal contaminated paddy field in Hunan Province, P. R. China [5]. Here we show that strain $\mathrm{TBZ}^{\mathrm{T}}{ }^{\mathrm{T}}$ is resistant to multiple heavy metals and remove $\mathrm{Zn}^{2+}$ and $\mathrm{Cd}^{2+}$. In

\footnotetext{
* Correspondence: gejiao@mail.hzau.edu.cn

* Correspondence: gejiao@mail.hzau.edu.cn and Technology, Huazhong Agricultural University, Wuhan 430070, People's Republic of China
} Republic of China

(c) The Author(s). 2018 Open Access This article is distributed under the terms of the Creative Commons Attribution 4.0 International License (http://creativecommons.org/licenses/by/4.0/), which permits unrestricted use, distribution, and reproduction in any medium, provided you give appropriate credit to the original author(s) and the source, provide a link to the Creative Commons license, and indicate if changes were made. The Creative Commons Public Domain Dedication waiver (http://creativecommons.org/publicdomain/zero/1.0/) applies to the data made available in this article, unless otherwise stated.

addition, strain $\mathrm{TBZ}^{\mathrm{T}}{ }^{\mathrm{T}}$ is able to produce EPS. The genomic information of strain $\mathrm{TBZ}^{\mathrm{T}}{ }^{\mathrm{T}}$ are provided.

\section{Organism information \\ Classification and features}

Similarity analysis was performed using neighbor-joining method based on the 16S rRNA gene sequences and a phylogenetic tree was constructed using MEGA version 6.0 software (Fig. 1). Bootstrap analysis with 1000 replications was conducted to obtain confidence levels of the branches. Strain $\mathrm{TBZ}^{\mathrm{T}}{ }^{\mathrm{T}}$ showed the highest $16 \mathrm{~S}$ rRNA gene sequence similarity with Mucilaginibacter gynuensis $\mathrm{YC} 7003^{\mathrm{T}}$ (95.8\%), Mucilaginibacter mallensis MP1X4 ${ }^{\mathrm{T}}$ (95.4\%) and Mucilaginibacter litoreus $\mathrm{BR}-18^{\mathrm{T}} \quad(95.4 \%) \quad[6-8]$ and grouped together with M. gynuensis $\mathrm{YC} 7003^{\mathrm{T}}$ (95.8\%) and M. mallensis $\mathrm{MP} 1 \mathrm{X} 4^{\mathrm{T}}$ (Fig. 1).

Strain $\mathrm{TBZ}^{\mathrm{T}}{ }^{\mathrm{T}}$ is Gram-negative, non-motile, and non-spore-forming. Cells are rod-shaped $(0.3-0.4 \times 1.1-$ $1.3 \mu \mathrm{m}$ ) (Fig. 2). Colonies are circular, pink, convex and smooth on R2A agar. Growth occurs aerobically at $4-28^{\circ} \mathrm{C}$ (optimum, $25^{\circ} \mathrm{C}$ ), $\mathrm{pH} 5.0-8.5$ (optimum, $\mathrm{pH} 7.0$ ), and in the presence of $0-1.0(w / v) \mathrm{NaCl}$ (optimum, without $\mathrm{NaCl}$ ) (Table 1) [5]. Oxidase- and catalase-positive [5]. It can use 


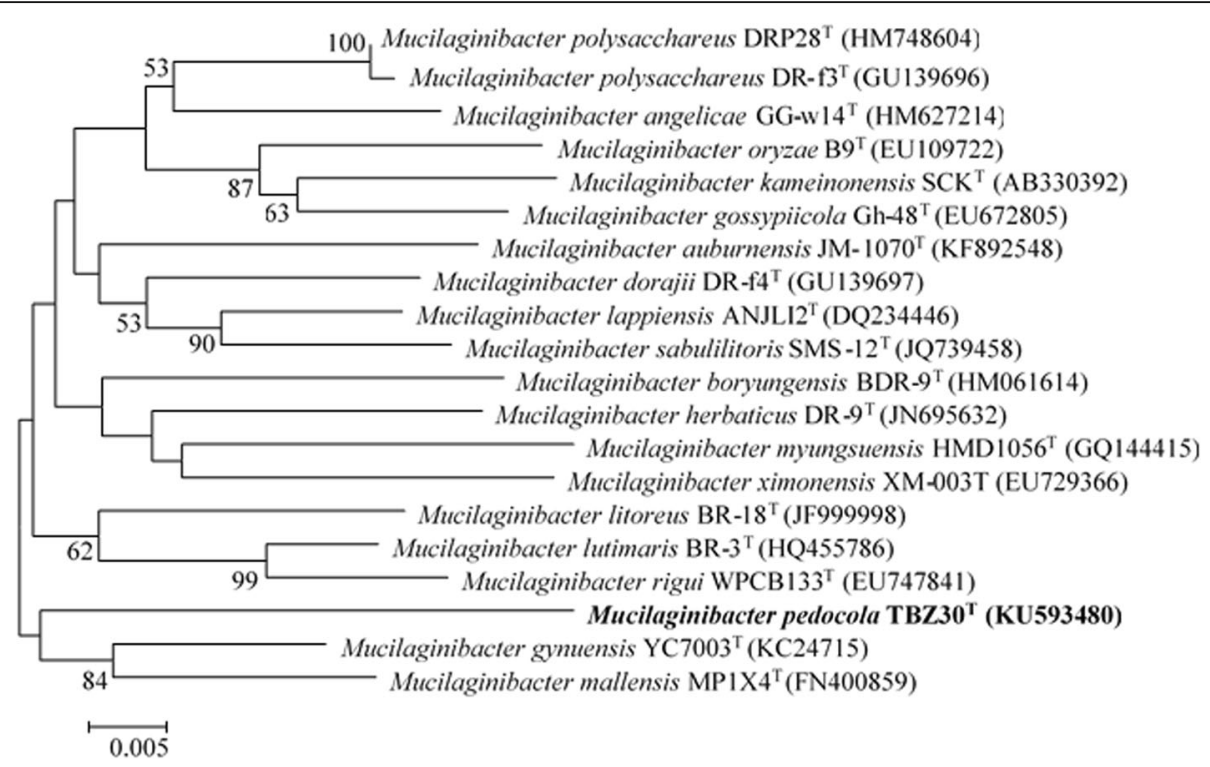

Fig. 1 A neighbor-joining phylogenetic tree based on 165 rRNA gene sequences showing the phylogenetic relationships of strain TBZ30 ${ }^{\top}$ and the related species. The bootstrap value less than $50 \%$ are not shown. Bar, 0.005 substitutions per nucleotide position

glucose, mannose, L-arabinose, maltose, melibiose, rhamnose and glycogen as the sole carbon sources [5]. Strain $\mathrm{TBZ}^{\mathrm{T}}{ }^{\mathrm{T}}$ can produce EPS testing by aniline blue staining method [9] (Fig. 3). The colonies of strain $\mathrm{TBZ}^{\mathrm{T}}{ }^{\mathrm{T}}$ and the known EPS producing strain $M$. litoreus $\mathrm{BR}-18^{\mathrm{T}}$ are pink on LB plates (Fig. 3a and b), while the colonies are blue on LB-aniline blue plate (Fig. $3 \mathrm{~d}$ and e). However, the colonies are always white for the negative control Nocardioides albus $\mathrm{KCTC} 9186^{\mathrm{T}}[10,11]$ on either $\mathrm{LB}$ or LB-aniline blue plates (Fig. $3 \mathrm{c}$ and $\mathrm{f}$ ). All of the above strains were incubated at $28^{\circ} \mathrm{C}$ for 7 days. In addition, strain $\mathrm{TBZ}^{\mathrm{T}} 0^{\mathrm{T}}$ is resistant to multiple heavy metals. The minimal inhibition concentration (MIC) tests for different heavy metals were performed on R2A agar plates at $28^{\circ} \mathrm{C}$ for 7 days. The MICs for $\mathrm{ZnSO}_{4}, \mathrm{CdCl}_{2}, \mathrm{PbSO}_{4}, \mathrm{CuSO}_{4}$ and $\mathrm{NaAsO}_{2}$ are $3.5 \mathrm{mM}, 1.5 \mathrm{mM}, 0.4 \mathrm{mM}, 1.2 \mathrm{mM}$ and

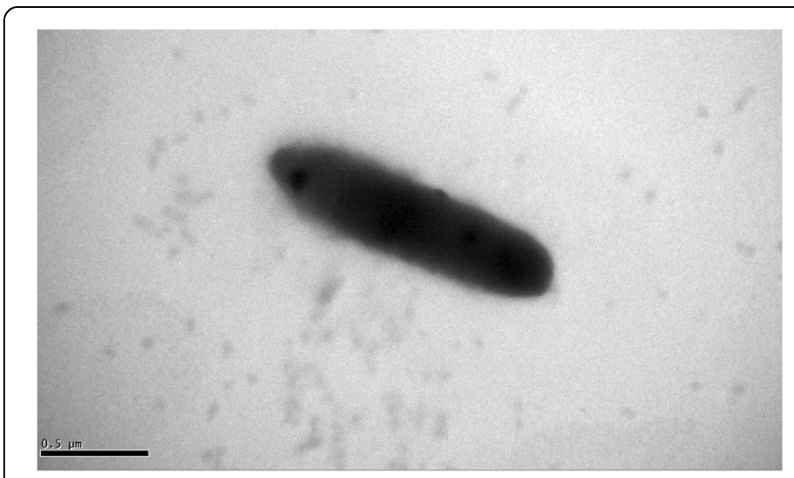

Fig. 2 A scanning electron microscope (SEM) image of Mucilaginibacter pedocola TBZ30T cells. The bar scale represents $0.5 \mu \mathrm{m}$
$0.35 \mathrm{mM}$, respectively. Furthermore, strain $\mathrm{TBZ}^{\mathrm{T}}{ }^{\mathrm{T}}$ could adsorb/remove nearly $60 \%$ of $\mathrm{Zn}^{2+}$ and $55 \%$ of $\mathrm{Cd}^{2+}$ in the $\mathrm{R} 2 \mathrm{~A}$ liquid medium (added with $0.3 \mathrm{mM} \mathrm{ZnSO}_{4}$ and 0.25 $\mathrm{mM} \mathrm{CdCl}$, respectively) (Fig. 4). The amount of the heavy metals were detected by an atomic absorption spectrometer.

\section{Genome information \\ Genome project history}

M. pedocola $\mathrm{TBZ}^{\mathrm{T}}{ }^{\mathrm{T}}$ was sequenced on the basis of its abilities of heavy metals resistance and removal, which has a great potential for bioremediation. The draft genome was sequenced by Wuhan Bio-Broad Co., Ltd., Wuhan, China. The high-quality-draft genome sequence has been deposited at DDBJ/EMBL/GenBank under the accession number MBTF00000000.1. The project information is shown in Table 2.

\section{Growth condition and DNA isolation}

M. pedocola $\mathrm{TBZ}^{\mathrm{T}}{ }^{\mathrm{T}}$ was grown in $\mathrm{R} 2 \mathrm{~A}$ medium at $28^{\circ}$ $\mathrm{C}$ for $36 \mathrm{~h}$ with continuous shaking at $120 \mathrm{rpm}$. Bacterial cells were harvested through centrifugation $(13,400 \times \mathrm{g}$ for $5 \mathrm{~min}$ at $4{ }^{\circ} \mathrm{C}$ ) and the total genomic DNA was extracted using the QiAamp kit (Qiagen, Germany). The quality and quantity of the DNA were determined using a spectrophotometer (NanoDrop 2000, Thermo).

\section{Genome sequencing and assembly}

Whole-genome DNA sequencing was performed in Bio-broad Co., Ltd., Wuhan, China using Illumina standard shotgun library and Hiseq2000 pair-end sequencing strategy [12]. For accuracy of assembly, low quality of the original sequence data reads were removed. The 
Table 1 Classification and general features of Mucilaginibacter pedocola TBZ30 [39]

\begin{tabular}{|c|c|c|c|}
\hline$\overline{M I G S I D}$ & Property & Term & Evidence code ${ }^{a}$ \\
\hline & Classification & Domain Bacteria & TAS [40] \\
\hline & & Phylum Actinobacteria & TAS $[41,42]$ \\
\hline & & Class Sphingobacteria & $\operatorname{TAS}[43,44]$ \\
\hline & & Order Sphingobacteriales & TAS $[45,46]$ \\
\hline & & Family Sphingobacteriaceae & TAS [47] \\
\hline & & Genus Mucilaginibacter & TAS [1] \\
\hline & & Species pedocola & TAS [5] \\
\hline & & Strain TBZ30 ${ }^{\top}\left(=\right.$ CCTCC AB $2015301^{\top}=$ KCTC 42833 $\left.{ }^{\top}\right)$ & \\
\hline & Gram stain & negative & TAS [5] \\
\hline & Cell shape & rod & TAS [5] \\
\hline & Motility & non & TAS [5] \\
\hline & Sporulation & non-sporulating & NAS \\
\hline & Temperature range & $4-28^{\circ} \mathrm{C}$ & TAS [5] \\
\hline & Optimum temperature & $25^{\circ} \mathrm{C}$ & TAS [5] \\
\hline & pH range; Optimum & $5.0-8.5,7.0$ & TAS [5] \\
\hline & Carbon source & glucose, mannose, L-arabinose, maltose, melibiose, rhamnose, rhamnose and glycogen & TAS [5] \\
\hline MIGS-6 & Habitat & paddy field with heavy metal & TAS [5] \\
\hline MIGS-6.3 & Salinity & $0-1 \% \mathrm{NaCl}(w / v)$, optimal at $0 \%$ & TAS [5] \\
\hline MIGS-22 & Oxygen requirement & aerobic & TAS [5] \\
\hline MIGS-15 & Biotic relationship & free-living & TAS [5] \\
\hline MIGS-14 & Pathogenicity & non-pathogen & NAS \\
\hline MIGS-4 & Geographic location & Linxiang city, Hunan province, China & TAS [5] \\
\hline MIGS-5 & Sample collection & 2014 & TAS [5] \\
\hline MIGS-4.1 & Latitude & N30 $10^{\circ} 54^{\prime \prime}$ & TAS [5] \\
\hline MIGS-4.2 & Longitude & $\mathrm{E} 109^{\circ} 28^{\prime} 16^{\prime \prime}$ & TAS [5] \\
\hline MIGS-4.4 & Altitude & not reported & \\
\hline
\end{tabular}

aEvidence code-TAS: Traceable Author Statement (i.e., a direct report exists in the literature); NAS: Non-traceable Author Statement (i.e., not directly observed for the living, isolated sample, but based on a generally accepted property for the species, or anecdotal evidence) [48]

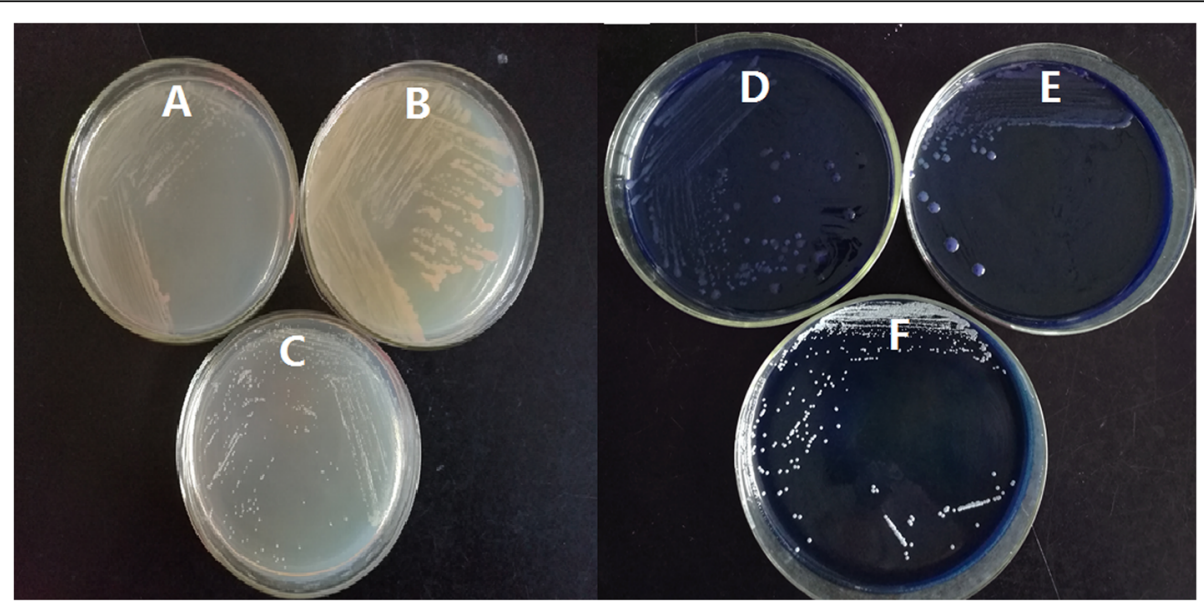

Fig. 3 EPS detection using the aniline blue staining method [9]. $\mathbf{a}, \mathbf{b}$ and $\mathbf{c}$ strain TBZ30 ${ }^{\top}$, positive control Mucilaginibacter litoreus BR-18 ${ }^{\top}$ and negative control Nocardioides albus KCTC $9186^{\top}$ cultivated in LB plates, respectively; (d, e and $\mathbf{f}$ ) the above three strains cultivated in LB-aniline blue plates, respectively 

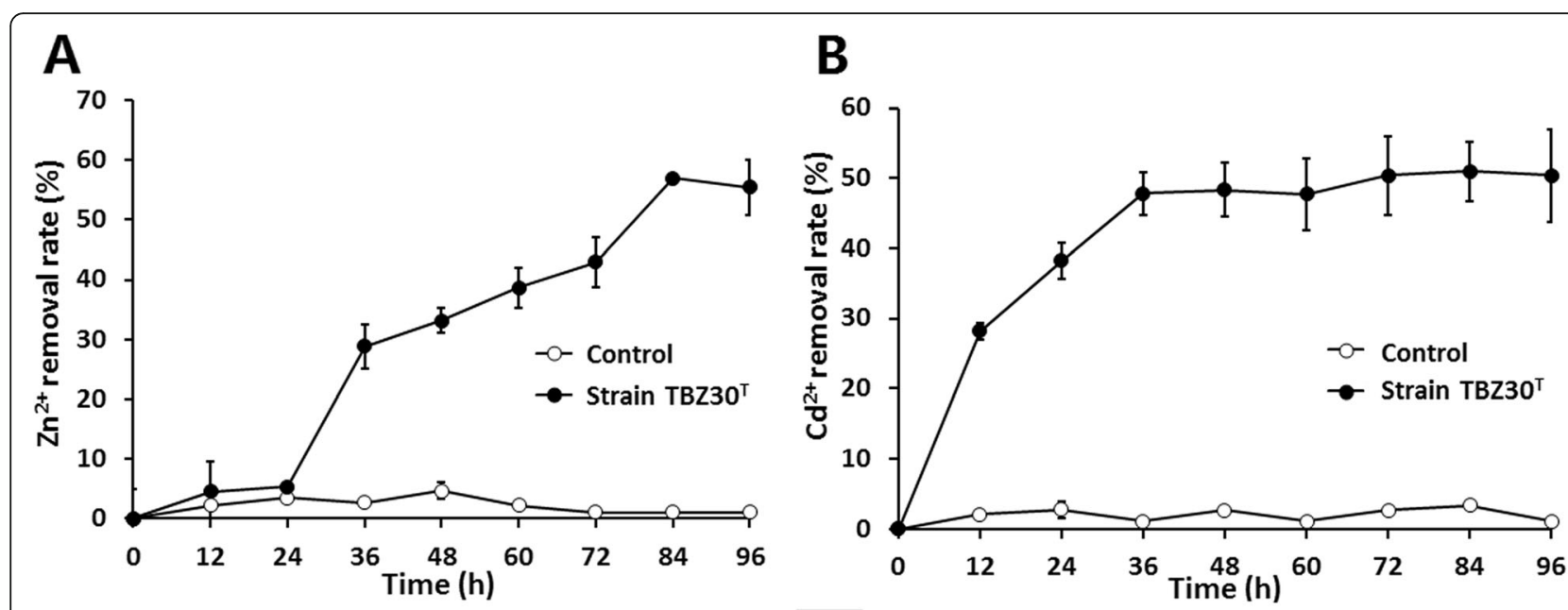

Fig. $4 \mathrm{Zn}^{2+}$ and $\mathrm{Cd}^{2+}$ removal by strain $T B Z 30^{\top}$ in $\mathrm{R} 2 \mathrm{~A}$ liquid media. a $\mathrm{Zn}^{2+}$ removal by strain $\mathrm{TBZ} 30^{\top}$; (b) $\mathrm{Cd}^{2+}$ removal by strain $\mathrm{TBZ} 30^{\top}$. The control represents $\mathrm{R} 2 \mathrm{~A}$ liquid medium with $0.3 \mathrm{mM} \mathrm{Zn}^{2+}$ or $0.25 \mathrm{mM} \mathrm{Cd}^{2+}$ without the inoculation of strain TBZ30'. Data are shown as the mean of three replicates

assembly of $\mathrm{TBZ30}^{\mathrm{T}}$ genome is based on $16,967,512$ quality reads totaling $2,523,391,653$ bases with a $377.50 \times$ average genome coverage. The final reads were assembled into 39 contigs (> $200 \mathrm{bp}$ ) using SOAPdenovo v2.04 [13]. The part gaps of assembly were filled and the error bases were revised using GapCloser v1.12 [14].

\section{Genome annotation}

The genome of strain $\mathrm{TBZ}^{\mathrm{T}}{ }^{\mathrm{T}}$ was annotated through the NCBI PGAP, which combined the gene caller GeneMarkS $^{+}$with the similarity-based gene detection approach [15]. Pseudo genes were predicted using the NCBI PGAP. Internal gene clustering was performed by

Table 2 Project information

\begin{tabular}{lll}
\hline MIGS ID & Property & Term \\
\hline MIGS-31 & Finishing quality & High-quality draft \\
MIGS-28 & Libraries used & $\begin{array}{l}\text { Illumina Paired-End library } \\
\text { (300 bp insert size) }\end{array}$ \\
MIGS-29 & Sequencing platforms & Illumina Miseq 2000 \\
MIGS-31.2 & Fold coverage & 377.50x \\
MIGS-30 & Assemblers & SOAPdenovo v2.04 \\
MIGS-32 & Gene calling method & GeneMarkS \\
& Locus TAG & BC343 \\
& Genbank ID & MBTF00000000.1 \\
& Genbank Date of Release & 04, 25, 2017 \\
& GoLD ID & Gs0134261 \\
& Bioproject & PRJNA331061 \\
& Source material identifier & Strain CCTCC AB 2015301 \\
MIGS-13 & Project relevance & Bioremediation \\
\hline
\end{tabular}

the OrthoMCL program using Match cutoff of $50 \%$ and E-value Exponent cutoff of 1-e5 [16, 17]. The COGs functional categories were assigned by the WebMGA server with E-value cutoff of 1-e10 [18]. The translations of the predicted CDSs were used to search against the Pfam protein family database and the KEGG database $[19,20]$. The transmembrane helices and signal peptides were predicted by TMHMM v. 2.0 and SignalP 4.1 , respectively $[21,22]$.

Table 3 Nucleotide content and gene count levels of the genome

\begin{tabular}{lll}
\hline Attribute & Value & \% of total \\
\hline Genome size (bp) & $7,035,113$ & 100 \\
DNA coding (bp) & $6,126,065$ & 87.1 \\
DNA G + C (bp) & $46.1 \%$ & 100 \\
DNA scaffolds & 38 & 100 \\
Total genes & 6072 & 100 \\
Protein-coding genes & 5935 & 97.7 \\
RNA genes & 67 & 1.1 \\
Pseudo genes & 70 & 1.2 \\
Genes in internal clusters & 587 & 9.7 \\
Genes with function prediction & 2736 & 45.1 \\
Genes assigned to COGs & 4046 & 66.6 \\
Genes with Pfam domains & 4434 & 73.0 \\
Genes with signal peptides & 1005 & 16.6 \\
Genes with transmembrane helices & 1407 & 23.2 \\
CRISPR repeats & 11 & 0.2 \\
\hline
\end{tabular}

The total is based on the size of the genome in base pairs and the total number of protein coding genes in the annotated genome 
Table 4 Number of genes associated with the 21 general COG functional categories

\begin{tabular}{|c|c|c|c|}
\hline COG class & count & $\%$ of total & description \\
\hline J & 160 & 2.70 & Translation, ribosomal structure and biogenesis \\
\hline A & 1 & 0.02 & RNA processing and modification \\
\hline K & 406 & 6.84 & Transcription \\
\hline L & 224 & 3.77 & Replication, recombination and repair \\
\hline B & 1 & 0.02 & Chromatin structure and dynamics \\
\hline D & 35 & 0.59 & Cell cycle control, cell division, chromosome partitioning \\
\hline V & 88 & 1.48 & Defense mechanisms \\
\hline T & 459 & 7.73 & Signal transduction mechanisms \\
\hline M & 389 & 6.55 & Cell wall/membrane/envelope biogenesis \\
\hline $\mathrm{N}$ & 23 & 0.39 & Cell motility \\
\hline$U$ & 87 & 1.47 & Intracellular trafficking, secretion, and vesicular transport \\
\hline O & 123 & 2.07 & Posttranslational modification, protein turnover, chaperones \\
\hline C & 185 & 3.12 & Energy production and conversion \\
\hline G & 337 & 5.68 & Carbohydrate transport and metabolism \\
\hline E & 247 & 4.16 & Amino acid transport and metabolism \\
\hline $\mathrm{F}$ & 73 & 1.23 & Nucleotide transport and metabolism \\
\hline $\mathrm{H}$ & 156 & 2.63 & Coenzyme transport and metabolism \\
\hline I & 162 & 2.73 & Lipid transport and metabolism \\
\hline P & 200 & 3.37 & Inorganic ion transport and metabolism \\
\hline Q & 106 & 1.79 & Secondary metabolites biosynthesis, transport and catabolism \\
\hline $\mathrm{R}$ & 593 & 9.99 & General function prediction only \\
\hline S & 431 & 7.26 & Function unknown \\
\hline- & 1449 & 24.41 & Not in COGs \\
\hline
\end{tabular}

The total is based on the total number of protein coding genes in the genome

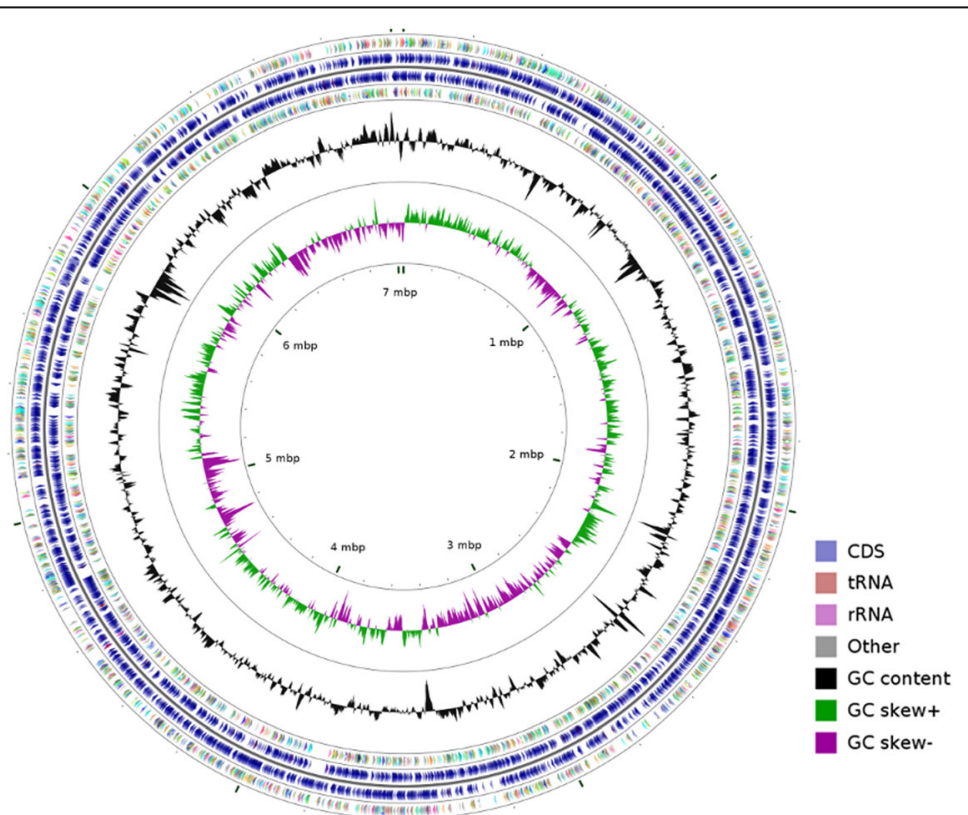

Fig. 5 A graphical circular map of Mucilaginibacter pedocola TBZ30 ${ }^{\top}$. From outside to center, rings 1, 4 show protein-coding genes colored by COG categories on forward/reverse strand; rings 2, 3 denote genes on forward/reverse strand; rings 5 show $\mathrm{G}+\mathrm{C} \%$ content; ring 6 shows $\mathrm{G}+\mathrm{C} \%$ content plot and the innermost ring shows GC skew 


\section{Genome properties}

The genome size of strain $\mathrm{TBZ}^{\mathrm{T}}{ }^{\mathrm{T}}$ is $7,035,113 \mathrm{bp}$ with an average $\mathrm{G}+\mathrm{C}$ content of $46.1 \%$ (Table 3). It has 6072 genes including 5935 protein-coding genes, 70 pseudo genes and 14 rRNA, 50 tRNA, and 3 ncRNA genes. The information of the genome statistics is shown in Table 3 and the classification of genes into COGs functional categories is summarized in Table 4. The graphical genome map is provided in Fig. 5.

\section{Insights from the genome sequence}

Strain $\mathrm{TBZ}^{\mathrm{T}}{ }^{\mathrm{T}}$ could be resistant to multiple heavy metals $\left(\mathrm{Zn}^{2+}, \mathrm{Cd}^{2+}, \mathrm{Pb}^{2+}, \mathrm{Cu}^{2+}\right.$ and $\left.\mathrm{As}^{3+}\right)$ and adsorb/ remove $\mathrm{Zn}^{2+}$ and $\mathrm{Cd}^{2+}$ during cultivation. Analyzing of its genome, various putative proteins related to multiple heavy metals resistance are found (Table 5). RND efflux systems (CzcABC), CDF efflux systems $(\mathrm{CzcD}$ and YieF) and P-type ATPases (HMA and ZntA) are responsible for the efflux of $\mathrm{Zn}^{2+}, \mathrm{Cd}^{2+}$ and $\mathrm{Pb}^{2+}[23-27$.

Table 5 Putative protein involved in heavy metals resistance and EPS production

\begin{tabular}{|c|c|c|}
\hline Heavy metals or EPS production & Putative function & Locus_tag of the predicted protein \\
\hline \multicolumn{3}{|l|}{ Zinc-Cadmium-Lead resistance } \\
\hline \multirow[t]{3}{*}{ RND efflux systems } & CusA/CzcA heavy metal efflux RND transporter & BC343_14685, BC343_14785 \\
\hline & Efflux RND transporter periplasmic adaptor subunit $\mathrm{CzCB}$ & BC343_14680, BC343_14795 \\
\hline & Outer membrane protein $\mathrm{CzcC}$ & BC343_14800 \\
\hline \multirow[t]{2}{*}{ CDF efflux systems } & Cation transporter $\mathrm{CzcD}$ & BC343_11185 \\
\hline & Cation transporter FieF & BC343_27530 \\
\hline \multirow[t]{3}{*}{ P-type ATPase } & Heavy metal translocating P-type ATPase HMA & BC343_08790 \\
\hline & Heavy metal translocating P-type ATPase ZosA & BC343_14675 \\
\hline & Cadmium-translocating P-type ATPase ZntA & BC343_00930 \\
\hline Zip super family & Zip family metal transporter & BC343_14670 \\
\hline \multirow[t]{3}{*}{ Copper resistance } & Zip family metal transporter & BC343_14670 \\
\hline & Heavy metal translocating P-type ATPase ZosA & BC343_14675 \\
\hline & Copper homeostasis protein CutC & BC343_23340 \\
\hline \multirow[t]{4}{*}{ Arsenic resistance } & Arsenite efflux pump ACR3 & BC343_02735 \\
\hline & Arsenate reductase ArsC & BC343_02740, BC343_24635 \\
\hline & Arsenite S-adenosylmethyltransferase ArsM & BC343_24640 \\
\hline & Arsenical resistance repressor ArsR & BC343_24645, BC343_02755 \\
\hline \multicolumn{3}{|c|}{ Nucleotide sugars biosynthesis for EPS production } \\
\hline \multirow[t]{3}{*}{ CDP-Glc } & Sugar kinase & BC343_21040, BC343_04390 \\
\hline & Phosphoglucomutas & BC343_18360 \\
\hline & Gucose-1-phosphate cytidylyltransferase RfbF & BC343_04660 \\
\hline ADP-Glc & Glucose-1-phosphate adenylyltransferase & BC343_23820 \\
\hline \multirow[t]{5}{*}{ GDP-D-man } & Glucose-6-phosphate isomerase & BC343_14065 \\
\hline & 6-phosphofructokinase & BC343_20710, BC343_25175 \\
\hline & Mannose-6-phosphate isomerase ManA & BC343_15810, BC343_21400 \\
\hline & Phosphoglucosamine mutase phosphomannomutase & BC343_21600 \\
\hline & Mannose-1-phosphate guanyly|transferase & BC343_03170 \\
\hline \multirow[t]{8}{*}{ EPS biosynthesis } & 3-Deoxy-D-manno-octulosonic-acid transferase KdtA & BC343_09425 \\
\hline & Priming glycosyltransferase CpsE & BC343_04560 \\
\hline & Glycosyltransferase & BC343_04600, BC343_09445 \\
\hline & ABC transporter KpsMT & BC343_09400, BC343_09585 \\
\hline & Polysaccharide co-polymerase protein PCP & BC343_04670 \\
\hline & Outer membrane polysaccharide protein OPX & BC343_04675 \\
\hline & Flippase Wzx & BC343_08105 \\
\hline & Capsular biosynthesis protein PHP & BC343_09405 \\
\hline
\end{tabular}


Zip family metal transporter and P-type ATPase ZosA are associated with the efflux of $\mathrm{Zn}^{2+}, \mathrm{Cd}^{2+}$ or $\mathrm{Cu}^{2+}$ [28-30], and CutC is involved in $\mathrm{Cu}^{2+}$ homeostasis [30-32]. Moreover, $\mathrm{As}^{3+}$ resistant proteins including arsenite efflux pump ACR3, arsenate reductase ArsC, arsenite S-adenosylmethyltransferase ArsM and arsenic resistance repressor ArsR are also found [33-35] (Table 5).

Strain $\mathrm{TBZ}^{\mathrm{T}}{ }^{\mathrm{T}}$ produces EPS during cultivation. According to KEGG analysis, the complete biosynthesis pathway of repeating units of nucleotide sugars are identified in the genome, including the biosynthesis of CDP-Glc, ADP-Glc and GDP-D-man (Table 5). Genes related to long-chain polysaccharide assembly are also found (Table 5). The EPS production pathway in strain $\mathrm{TBZ}^{\mathrm{T}}{ }^{\mathrm{T}}$ appears to belong to ABC transporter dependent pathway [36]. First, the 3-deoxy-D-manno-octulosonic-acid transferase ( $\mathrm{KdtA})$ is responsible for the synthesis of poly-Kdo linker using either diacyl or monoacyl phosphatidylglycerol as the substrate [36]; Then priming glycosyltransferase (CpsE) catalyzes the transformation of the first repeating unit to the poly-Kdo linker; Next, glycosyltransferases catalyze the synthesis of EPS repeat-unit; Finally, the polymerized repeat-units are exported through an envelope-spanning complex consisting of $\mathrm{ABC}$ transporter (KpsMT), polysaccharide co-polymerase protein (PCP) and outer membrane polysaccharide protein (OPX) [37, 38]. In addition, strain $\mathrm{TBZ}^{\mathrm{T}}{ }^{\mathrm{T}}$ genome owns a flippase (Wzx) which catalyzes the translocation of repeat-units crossing the cytoplasmic membrane. EPS have been reported to play an important role in metal removal [3]. Therefore, it is possible that the EPS of strain $\mathrm{TBZ}^{\mathrm{T}}{ }^{\mathrm{T}}$ participate in $\mathrm{Zn}^{2+}$ and $\mathrm{Cd}^{2+}$ removal by adsorption.

\section{Conclusions}

To the best of our knowledge, this study presents the first genomic information of a Mucilaginibacter type strain. The data reveal good correlation between genotypes and phenotypes. The genome information and the features provide insights for further theoretical and applied analysis of $M$. pedocola $\mathrm{TBZ}^{\mathrm{T}}{ }^{\mathrm{T}}$ and the related Mucilaginibacter members.

\section{Abbreviations}

EPS: Exopolysaccharides; MIC: Minimal inhibition concentration

\section{Funding}

This study was supported by National key research and development program of China (2016YFD0800702).

\section{Authors' contributions}

XF and JT performed the phenotypic characterization, the data analysis and wrote the manuscript. LN participated in phenotypic experiments. JH participated in data analysis. GW was responsible for research design and revised the manuscript. All authors read and approved the final manuscript.

\section{Competing interests}

The authors declare that they have no competing interests.

\section{Publisher's Note}

Springer Nature remains neutral with regard to jurisdictional claims in published maps and institutional affiliations.

Received: 22 March 2018 Accepted: 10 November 2018

Published online: 28 November 2018

References

1. Pankratov TA, Tindall BJ, Liesack W, Dedysh SN. Mucilaginibacter paludis gen. nov., sp. nov. and Mucilaginibacter gracilis sp. nov., pectin-, xylan- and laminarin-degrading members of the family Sphingobacteriaceae from acidic Sphagnum peat bog. Int J Syst Evol Microbiol. 2007;57(10):2349-54.

2. Baik KS, Park SC, Kim EM, Lim CH, Seong CN. Mucilaginibacter rigui sp. nov., isolated from wetland freshwater, and emended description of the genus Mucilaginibacter. Int J Syst Evol Microbiol. 2010;60(1):134-9.

3. Cui $Y, X u T$, Qu X, Hu T, Jiang X, Zhao C. New insights into various production characteristics of Streptococcus thermophilus strains. Int J Mol Sci. 2016;17(10):1701.

4. More TT, Yadav JS, Yan S, Tyagi RD, Surampalli RY. Extracellular polymeric substances of bacteria and their potential environmental applications. J Environ Manag. 2014;144:1-25.

5. Tang J, Huang J, Qiao Z, Wang R, Wang G. Mucilaginibacter pedocola sp. nov., isolated from a heavy-metal-contaminated paddy field. Int J Syst Evol Microbiol. 2016;66(10):4033-8.

6. Khan H, Chung EJ, Jeon CO, Chung YR. Mucilaginibacter gynuensis sp. nov., isolated from rotten wood. Int J Syst Evol Microbiol. 2013;63(9):3225-31.

7. Mannisto MK, Tiirola M, McConnell J, Haggblom MM. Mucilaginibacter frigoritolerans sp. nov., Mucilaginibacter lappiensis sp. nov. and Mucilaginibacter mallensis sp. nov., isolated from soil and lichen samples. Int J Syst Evol Microbiol. 2010;60(12):2849-56.

8. Yoon JH, Kang SJ, Park S, Oh TK. Mucilaginibacter litoreus sp. nov., isolated from marine sand. Int J Syst Evol Microbiol. 2012;62(12):2822-7.

9. $K N$, Devasya RP, Bhagwath AA. Exopolysaccharide produced by Enterobacter sp. YG4 reduces uranium induced nephrotoxicity. Int J Biol Macromol. 2016;82:557-61.

10. Prauser $\mathrm{H}$. Nocardioides, a new genus of the order actinomycetales. Int J Syst Evol Microbiol. 1976;26:58-65.

11. Skerman VBD, McGowan V, Sneath PHA. Approved lists of bacterial names. Int J Syst Bacteriol. 1980:30:225-420.

12. Bennett S. Solexa Ltd. Pharmacogenomics. 2004;5(4):433-8.

13. Luo R, Liu B, Xie Y, Li Z, Huang W, Yuan J, et al. SOAPdenovo2: an empirically improved memory-efficient short-read de novo assembler. GigaScience. 2012;1(1):18.

14. Li R, Zhu H, Ruan J, Qian W, Fang X, Shi Z, et al. De novo assembly of human genomes with massively parallel short read sequencing. Genome Res. 2010;20(2):265-72

15. Besemer J, Lomsadze A, Borodovsky M. GeneMarkS: a self-training method for prediction of gene starts in microbial genomes. Implications for finding sequence motifs in regulatory regions. Nucleic Acids Res. 2001;29(12):2607-18.

16. Li L, Stoeckert CJ Jr, Roos DS. OrthoMCL: identification of ortholog groups for eukaryotic genomes. Genome Res. 2003;13(9):2178-89.

17. Fischer S, Brunk BP, Chen F, Gao X, Harb OS, lodice JB, et al. Using OrthoMCL to assign proteins to OrthoMCL-DB groups or to cluster proteomes into new ortholog groups. Curr Protoc Bioinformatics. 2011;6:1-19.

18. Wu S, Zhu Z, Fu L, Niu B, Li W. WebMGA: a customizable web server for fast metagenomic sequence analysis. BMC Genomics. 2011;12:444.

19. Finn RD, Bateman A, Clements J, Coggill P, Eberhardt RY, Eddy SR, et al. Pfam: the protein families database. Nucleic Acids Res. 2014;42:222-30.

20. Kanehisa M, Goto S, Kawashima S, Okuno Y, Hattori M. The KEGG resource for deciphering the genome. Nucleic Acids Res. 2004;32:277-80.

21. Krogh A, Larsson B, von Heijne G, Sonnhammer EL. Predicting transmembrane protein topology with a hidden Markov model: application to complete genomes. J Mol Biol. 2001;305(3):567-80.

22. Petersen TN, Brunak S, Von Heijne G, Nielsen H. SignalP 4.0: discriminating signal peptides from transmembrane regions. Nat Methods. 2011:8(10):785-6.

23. Nies DH. CzcR and $\mathrm{CzCD}$, gene products affecting regulation of resistance to cobalt, zinc, and cadmium (czc system) in Alcaligenes eutrophus. J Bacteriol. 1992;174(24):8102-10. 
24. Nies DH. Efflux-mediated heavy metal resistance in prokaryotes. FEMS Microbiol Rev. 2003;27(2-3):313-39.

25. Xiong J, Li D, Li H, Susan J, Miller LY, et al. Genome analysis and characterization of zinc efflux systems of a highly zinc-resistant bacterium, Comamonas testosteroni S44. Res Microbiol. 2011;162(7):671-9.

26. Rakesh S, Christopher R, Barry PR, Bharati M. The ATP hydrolytic activity of purified $\mathrm{ZntA}, \mathrm{PB}(\mathrm{II}) / \mathrm{cd}(\mathrm{II}) / \mathrm{Zn}(\mathrm{II})$-translocating ATPase from Escherichia coli. J Biol Chem. 2000;275:3873-8.

27. Solioz M, Vulpe C. CPx-type ATPases: a class of P-type ATPases that pump heavy metals. Trends Biochem Sci. 1996;21 (7):237-41.

28. Li S, Zhou X, Huang Y, Zhu L, Zhang S, Zhao Y, et al. Identification and characterization of the zinc-regulated transporters, iron-regulated transporterlike protein (ZIP) gene family in maize. BMC Plant Biol. 2013;13:114.

29. Potocki $\mathrm{S}$, Valensin $\mathrm{D}$, Kozlowski $\mathrm{H}$. The specificity of interaction of $\mathrm{Zn}(2+)$, $\mathrm{Ni}(2+)$ and $\mathrm{cu}(2+)$ ions with the histidine-rich domain of the TjZNT1 ZIP family transporter. Dalton Trans. 2014;43(26):10215-23.

30. Guan G, Pinochet-Barros A, Gaballa A, Patel SJ, Argüello JM, Helmann JD. PfeT, a P1B4 -type ATPase, effluxes ferrous iron and protects Bacillus subtilis against iron intoxication. Mol Microbiol. 2015;98(4):787-803.

31. Yong-Qun Z, De-Yu Z, Hong-Xia L, Na Y, Gen-Pei L, Da-Cheng W. Purification and preliminary crystallographic studies of CutC, a novel copper homeostasis protein from Shigella flexneri. Protein Pept Lett. 2005;12:823-82.

32. Mauricio L, Felipe O, Reyes-Jara A, Guadalupe L, Mauricio G. CutC is induced late during copper exposure and can modify intracellular copper content in Enterococcus faecalis. Biochem Biophys Res Commun. 2011;406:633-7.

33. Liu G, Liu M, Kim EH, Maaty WS, Bothner B, Lei B, et al. A periplasmic arsenite-binding protein involved in regulating arsenite oxidation. Environ Microbiol. 2012;14(7):1624-34.

34. Li X, Zhang L, Wang G. Genomic evidence reveals the extreme diversity and wide distribution of arsenic-related genes in Burkholderides. PLoS One. 2014;9(3):e92236.

35. Qin J, Zhang Y, Barry R, Wang G, Franke S, Rensing C. Arsenic detoxification and evolution of trimethylarsine gas by microbial arsenite $\mathrm{S}$-adenosylmethionine methyltransferase. Proc Natl Acad Sci. 2006;103(7):2075-80.

36. Schmid J, Sieber V, Rehm B. Bacterial exopolysaccharides: biosynthesis pathways and engineering strategies. Front Microbiol. 2015;6:496.

37. Cuthbertson L, Mainprize IL, Naismith JH, Whitfield C. Pivotal roles of the outer membrane polysaccharide export and polysaccharide copolymerase protein families in export of extracellular polysaccharides in gram-negative bacteria. Microbiol Mol Biol Rev. 2009;73(1):155-77.

38. Willis $L M$, Whitfield C. Structure, biosynthesis, and function of bacterial capsular polysaccharides synthesized by $A B C$ transporter-dependent pathways. Carbohydr Res. 2013;378:35-44

39. Field D, Garrity G, Gray T, Morrison N, Selengut J, Sterk P, et al. The minimum information about a genome sequence (MIGS) specification. Nat Biotechnol. 2008:26:541-7.

40. Woese CR, Kandler O, Wheelis ML. Towards a natural system of organisms: proposal for the domains archaea, Bacteria, and Eucarya. Proc Natl Acad Sci U S A. 1990;87:4576-9.

41. Goodfellow M. Phylum XXVI. Actinobacteria phyl. nov. Bergey's Manual of Systematic Bacteriology 2012;5; Part A:33.

42. Stackebrandt E, Rainey FA, Ward-Rainey NL. Proposal for a new hierarchic classification system, Actinobacteria classis nov. Int I Syst Evol Microbiol. 1997:47:479-91.

43. Smith C. The neomuran origin of archaebacteria, the negibacterial root of the universal tree and bacterial megaclassification. Int I Syst Evol Microbiol. 2002:52:7-76.

44. Euzéby J. Validation list no. 143. List of new names and new combinations previously effectively, but not validly, published. Int J Syst Evol Microbiol. 2012;62:1-4.

45. Kämpfer P. Class III. Sphingobacteriia class. nov. Bergey's Manual of Systematic Bacteriology, vol. 4; 2011. p. 330.

46. Kämpfer P. Order I. Sphingobacteriales ord nov Bergey's Manual of Systematic Bacteriology, vol. 4; 2011. p. 330.

47. Steyn PL, Segers P, Vancanneyt M, Sandra P, Kersters K, Joubert J. Classification of heparinolytic bacteria into a new genus, Pedobacter, comprising four species: Pedobacter heparinus comb. nov., Pedobacter piscium comb. nov. Pedobacter africanus sp. nov. and Pedobacter saltans sp. nov. Proposal of the family Sphingobacteriaceae fam. nov. Int J Syst Bacteriol. 1998:48:165-77.

48. Ashburner M, Ball CA, Blake JA, Botstein D, Butler H, Cherry JM, et al. Geneontology: tool for the unification of biology. The gene ontology consortium. Nat Genet. 2000;25:25-9.

Ready to submit your research? Choose BMC and benefit from:

- fast, convenient online submission

- thorough peer review by experienced researchers in your field

- rapid publication on acceptance

- support for research data, including large and complex data types

- gold Open Access which fosters wider collaboration and increased citations

- maximum visibility for your research: over $100 \mathrm{M}$ website views per year

At $\mathrm{BMC}$, research is always in progress.

Learn more biomedcentral.com/submissions 